\title{
Identification of Sources of Resistance in Saffron (Crocus sativus L.) to Fusarium oxysporum Causing Corm Rot Disease
}

\author{
Sabiya Bashir ${ }^{1 *}$, Mohammad Najeeb Mughal ${ }^{2}$, F.A. Nehvi ${ }^{1}$, S.A. Dar ${ }^{1}$, Seerat un nissa ${ }^{1}$, \\ Z.A. Dar ${ }^{1}$, S.A. Hakeem ${ }^{1}$, R.A. Wani ${ }^{1}$, Jahangeer A. Baba ${ }^{1}$ and Mehfooza Habib ${ }^{1}$ \\ ${ }^{1}$ Dryland (Karewa) Agriculture Research Station, Budgam, Sher-i-Kashmir University of \\ Agricultural Sciences and Technology of Kashmir, Shalimar, Srinagar-190025, India \\ ${ }^{2}$ Faculty of Agriculture and Regional Research Station Wadura, Maharashtra, India \\ *Corresponding author
}

\section{A B S T R A C T}

\begin{tabular}{|l|}
\hline K e y w o r d s \\
Disease incidence, \\
Fusarium oxysporum, \\
Genotypes, \\
Resistance, Saffron
\end{tabular}

Of the fifty-five saffron genotypes/ lines screened for resistance to Fusarium oxysporum during two consecutive years at Dryland Agriculture Research Station in Kashmir, indicated that disease incidence and disease intensity ranged from 2.50 to 81.50 per cent and 0.25 to $72.25 \%$, respectively. The highest mean disease incidence $(81.50 \%)$ was recorded in genotype SDM-102 and while lowest mean disease incidence $(2.5 \%)$ was recorded in genotype $0.75 \mathrm{Kr}$. Among the screened genotypes/lines, 'Highly Resistant' genotypes are $0.5 \mathrm{Kr}, 0.75 \mathrm{Kr}$, SMD-1, SMD-3 SMD-27, SMD146, SD-147, SD-224 SD-45, SD-52, SD-68, while 'highly susceptible' genotypes were SMD-102 and SMD-103.

\section{Introduction}

Saffron (Crocus sativus L.) world's most sought after and expensive spice is an important spice cash crop of Kashmir. There are more than 2 lakh people who are directly or indirectly involved with the saffron trade. The crop covers an area of 5000 acres (2023 ha) in Jammu and Kashmir. Saffron is especially grown in uplands and karewa areas of Kashmir valley especially Pampore and adjoining areas. The other place where saffron is grown includes Budgam, Pulwama and Anantnag in Kashmir valley and Kishtwar district in Jammu Division. Saffron covers about $4 \%$ of total cultivated areas of Kashmir valley and provides about $6 \%$ of total agricultural income (Mir, 1992).

The yield of saffron dwindles year after year. The average productivity in $\mathrm{J} \& \mathrm{~K}$ reached to $2.7 \mathrm{~kg}$ as against $3.29 \mathrm{~kg} / \mathrm{ha}$ in 1997 (Zargar, 2002). The decline in production continues though the newer areas are being are brought under its cultivation. The intensive cultivation and mono-culturing of saffron in saffron growing belts of valley together with the continual use of diseased material resulted in frequent occurrence of saffron corm rot diseases incited by pathogens like 
Phomacrocrophila, Rhizoctonia crocorum (sheath blight and corm rot), (Madan et al., 1967), Fusarium moniliforme var intermedium, non sporulating basidiomycetous fungus (Dhar, 1992), Macrophomina phaseolina (Thakur et al., 1992), Fusarium oxysporum, F. solani, F. pallidoroseum, F.equiseti, Mucorspp, Penicillium spp (Wani,2004, Ahmed and Sagar, 2006), Sclerotium rolfsii (Kalhaet al., 2007). Of these diseases, corm rot of saffron caused by Fusarium oxysporum and $F$. solani is considered most destructive (Wani, 2004; Ahmed and Sagar, 2007) and takes considerable proportion of the produce every year. Dhar (1992) reported 6.7 to 15.2 per cent corm rot disease incidence and observed that none of the saffron growing areas in Kashmir valley was free from this disease. Thakur (1997), however, reported corm rot incidence to the magnitude of 70 to 85 per cent in saffron growing fields of Kashmir. The review of work done on this aspect suggested that the evaluation of a much broader range of germplasm of saffron is required for corm rot pathogen. Keeping in view the losses inflicted by this diseases and the need to devise its management with emphasis on use of resistant genotypes, in the present study, an attempt was made to identify sources of resistance to the disease in available germplasm under temperate climatic conditions of Kashmir valley.

\section{Materials and Methods}

Fifty-five saffron genotypes/ lines collected from various places were screened against the pathogen under natural epiphytotic conditions at Dryland Agriculture Research Station, SKUAST-K for two consecutive years. Each line was sown with plant to plant distance of $10 \mathrm{~cm}$ and row to row distance of $20 \mathrm{~cm}$. The plot was flanked on both sides with double row of a highly susceptible variety 'SMD102 ' and each test row was followed by a row of the same susceptible cultivar 'SMD-102'.
Three replications were maintained for each genotype. The disease reaction was recorded on by using modified 0-5 scale (Gupta et al., 2000), where 0 denotes completely disease free corms and 5 denotes the extent of infection covering more than 50\% corm area. The genotypes were classified into highly resistant (0-5\% disease intensity), resistant (5.1-10\% disease intensity), moderately resistant (10.1-20.0\% disease intensity), susceptible (20.1-50.0\% disease intensity) and highly susceptible (more than 50\% disease intensity) categories.

\section{Results and Discussion}

The screening of saffron against corm rot disease during first year of experimentation indicated that disease incidence and disease intensity ranged from 2.50 to $85.00 \%$ and 0.25 to $79.50 \%$, respectively. The highest disease incidence $(85.00 \%)$ was recorded in genotype SDM-102 while lowest disease incidence $(2.5 \%)$ was recorded in SDM-1 genotype. Among the screened germplasm, 'Highly Resistant' genotypes were SMD-1, SMD-27, SMD-46, SMD-93, SMD-156, SD31, SD-45, SD-52, SD-68, SD-81, SD-147, SD-224, and.75Kr, while 'highly susceptible' genotypes were SMD-98, SMD-102, SMD103, and SMD-207. However, during the second year of experimentation, disease incidence and disease intensity ranged from 2.50 to 78.0 per cent and 0.25 to 64.0 per cent respectively Most of genotypes showed similar trends as in 2009. The highest disease incidence $(78.0 \%)$ was recorded in genotype SDM-102 while lowest disease incidence $(2.5 \%)$ was recorded in SDM-1, SD-45 and.7 $\mathrm{Kr}$ genotype. Among the screened germplasm, 'Highly Resistant' genotypes were $0.5 \mathrm{Kr}, 0.75 \mathrm{Kr}$, SMD-1, SMD-3 SMD27, SMD-146, SD-147, SD-224 SD-45, SD52, SD- 68, while 'highly susceptible' genotypes were SMD-102, SMD-98, SMD103. 
Table.1 Screening of saffron genotypes/ lines against corm rot pathogen (Fusarium oxysporum) during two years of experimentation at DARS, Budgam

\begin{tabular}{|c|c|c|c|c|c|c|c|}
\hline \multirow{2}{*}{ S. No. } & \multirow{2}{*}{ Germplasm } & \multicolumn{2}{|c|}{ Disease incidence (\%) } & \multirow[b]{2}{*}{ Mean } & \multicolumn{2}{|c|}{ Disease intensity (\%) } & \multirow[b]{2}{*}{ Mean } \\
\hline & & Ist & $2^{\text {nd }}$ & & Ist & $2^{\text {nd }}$ & \\
\hline 1 & SMD-161 & 10.00 & 12.00 & 11.00 & 6.25 & 7.50 & 6.87 \\
\hline 2 & SMD-101 & 42.50 & 45.00 & 43.75 & 35.50 & 17.50 & 26.50 \\
\hline 3 & SMD-87 & 37.50 & 39.00 & 38.25 & 25.5 & 18.20 & 21.85 \\
\hline 4 & SMD-61 & 30.00 & 32.00 & 31.00 & 16.50 & 11.70 & 14.10 \\
\hline 5 & $0.25 \mathrm{Kr}$ & 20.00 & 18.00 & 19.00 & 9.75 & 7.50 & 8.62 \\
\hline 6 & $0.5 \mathrm{Kr}$ & 7.50 & 8.00 & 7.75 & 5.75 & 3.70 & 4.72 \\
\hline 7 & $0.75 \mathrm{Kr}$ & 2.50 & 2.50 & 2.50 & 0.25 & 0.20 & 0.22 \\
\hline 8 & $1 \mathrm{Kr}$ & 37.50 & 35.00 & 36.25 & 28.75 & 17.50 & 23.12 \\
\hline 9 & SMD-152 & 12.50 & 15.00 & 13.75 & 9.00 & 7.25 & 8.12 \\
\hline 10 & SMD-133 & 27.50 & 32.00 & 29.75 & 15.00 & 21.70 & 18.35 \\
\hline 11 & SMD-93 & 12.50 & 15.50 & 14.00 & 4.00 & 7.20 & 5.60 \\
\hline 12 & SMD-1 & 2.50 & 2.50 & 2.50 & 0.25 & 0.25 & 0.25 \\
\hline 13 & SMD-102 & 85.00 & 78.00 & 81.50 & 80.50 & 64.00 & 72.25 \\
\hline 14 & SMD-98 & 65.00 & 64.00 & 64.50 & 60.00 & 45.20 & 52.60 \\
\hline 15 & SMD-170 & 32.50 & 37.50 & 35.00 & 25.50 & 27.50 & 26.50 \\
\hline 16 & SMD-80 & 17.50 & 22.50 & 20.00 & 12.50 & 13.00 & 12.75 \\
\hline 17 & SMD-165 & 35.50 & 35.00 & 35.25 & 30.00 & 17.50 & 23.75 \\
\hline 18 & SMD-27 & 5.00 & 7.50 & 6.25 & 3.00 & 3.70 & 3.35 \\
\hline 19 & SMD-13 & 15.00 & 12.50 & 13.75 & 6.75 & 7.50 & 7.12 \\
\hline 20 & SMD-103 & 62.50 & 60.00 & 61.25 & 60.00 & 55.50 & 57.75 \\
\hline 21 & SMD-124 & 35.00 & 40.00 & 37.50 & 30.00 & 33.00 & 31.50 \\
\hline 22 & SMD-157 & 12.50 & 15.50 & 14.00 & 4.50 & 8.00 & 6.25 \\
\hline 23 & SMD-47 & 12.50 & 15.00 & 13.75 & 2.75 & 8.00 & 5.37 \\
\hline 24 & SMD-45 & 40.00 & 35.00 & 37.50 & 27.00 & 17.50 & 22.25 \\
\hline 25 & SMD-3 & 42.50 & 40.00 & 41.25 & 33.00 & 21.70 & 27.35 \\
\hline 26 & SMD-11 & 17.50 & 15.50 & 16.50 & 13.50 & 8.50 & 11.00 \\
\hline 27 & SMD-111 & 60.00 & 65.00 & 62.50 & 49.50 & 30.50 & 40.00 \\
\hline 28 & SMD-146 & 17.50 & 15.00 & 16.25 & 15.75 & 3.70 & 9.72 \\
\hline 29 & SMD-217 & 25.00 & 17.50 & 21.25 & 17.2 & 13.00 & 15.10 \\
\hline 30 & SMD-76 & 35.00 & 40.00 & 37.50 & 17.5 & 10.00 & 13.75 \\
\hline 31 & SMD-68 & 25.00 & 27.50 & 26.25 & 14.5 & 15.50 & 15.00 \\
\hline 32 & SMD-52 & 15.00 & 12.50 & 13.75 & 7.25 & 5.20 & 6.22 \\
\hline 33 & SMD-54 & 40.00 & 42.50 & 41.25 & 33.0 & 30.50 & 31.75 \\
\hline 34 & SD-21 & 12.50 & 17.00 & 14.75 & 7.5 & 8.00 & 7.75 \\
\hline 35 & SD-1 & 25.00 & 22.50 & 23.75 & 18.25 & 9.70 & 13.97 \\
\hline 36 & SD-175 & 32.50 & 35.00 & 33.75 & 11.75 & 16.50 & 14.12 \\
\hline 37 & SMD-202 & 22.50 & 20.00 & 21.25 & 15.00 & 13.00 & 14.00 \\
\hline 38 & SD-35 & 22.50 & 15.50 & 19.00 & 14.25 & 10.00 & 12.12 \\
\hline 39 & SD-81 & 7.50 & 10.00 & 8.75 & 3.0 & 6.20 & 4.60 \\
\hline 40 & SD-13 & 25.00 & 18.00 & 21.50 & 18.25 & 13.00 & 15.62 \\
\hline 41 & SMD-79 & 40.00 & 37.50 & 38.75 & 18.5 & 25.50 & 22.00 \\
\hline 42 & SD-147 & 7.50 & 10.00 & 8.75 & 0.75 & 2.50 & 1.62 \\
\hline 43 & SD-40 & 22.50 & 27.50 & 25.00 & 16.75 & 15.00 & 15.87 \\
\hline 44 & SMD-186 & 30.00 & 32.50 & 31.25 & 21.75 & 18.00 & 19.87 \\
\hline 45 & SMD-207 & 55.00 & 60.00 & 57.50 & 50.25 & 45.20 & 47.72 \\
\hline 46 & SD-80 & 20.00 & 17.50 & 18.75 & 13.00 & 14.20 & 13.60 \\
\hline 47 & SMD-224 & 50.00 & 42.50 & 46.25 & 47.5 & 30.50 & 39.00 \\
\hline 48 & SD-180 & 12.50 & 12.50 & 12.50 & 5.25 & 7.50 & 6.37 \\
\hline 49 & SMD-192 & 15.00 & 17.50 & 16.25 & 8.0 & 7.20 & 7.60 \\
\hline 50 & SD-211 & 60.00 & 62.50 & 61.25 & 21.75 & 18.50 & 20.12 \\
\hline 52 & SD-224 & 7.50 & 5.00 & 6.25 & 1.00 & 0.75 & 0.87 \\
\hline 53 & SD-31 & 7.50 & 12.00 & 9.75 & 3.75 & 5.20 & 4.47 \\
\hline 54 & SD-45 & 5.00 & 2.50 & 3.75 & 3.50 & 2.00 & 2.75 \\
\hline 55 & SD-52 & 7.50 & 5.00 & 6.25 & 3.50 & 2.50 & 3.00 \\
\hline
\end{tabular}


Table.2 Categorization of fifty five saffron genotypes on the basis of disease reaction types on corms at DARS Budgam, during two years

\begin{tabular}{|c|c|c|}
\hline Category & $\begin{array}{c}\text { Disease intensity } \\
\text { range }(\%)\end{array}$ & Genotype \\
\hline Highly resistant (HR) & $0.5-5.0$ & $\begin{array}{l}\text { 0.5Kr, 0.75Kr,SMD-1, SMD-3,SMD-27, } \\
\text { SMD-146, SD-147, SD-224,SD-45, SD- } \\
\text { 52, SD- } 68\end{array}$ \\
\hline Resistant (R) & $5.1-10.0$ & $\begin{array}{l}\text { SMD-161,0.25 Kr,SMD-152, SMD-93, } \\
\text { SMD-13, SMD-157, SMD-47, SMD-11, } \\
\text { SMD-76, SMD-52, SD-21, SD-1, SD-35, } \\
\text { SD-81, SD-180, SMD-192, SD-31 }\end{array}$ \\
\hline $\begin{array}{l}\text { Moderately resistant } \\
(\mathrm{MR})\end{array}$ & $10.1-20.0$ & $\begin{array}{l}\text { SMD-101, SMD-87, SMD-61, } 1 \mathrm{Kr}, \\
\text { SMD-133, SMD-80, SMD-165 SMD-45, } \\
\text { SMD-217, SMD-68, SMD-175, SMD- } \\
\text { 202, SMD-13, SD-40, SMD-186, SD- } \\
\text { 211. }\end{array}$ \\
\hline Susceptible (S) & $20.1-50.0$ & $\begin{array}{l}\text { SMD-98, SMD-170 SMD-124, SMD-3, } \\
\text { SMD-111, SMD-54, SMD-79, SMD-207 } \\
\text { SMD- SMD-224. }\end{array}$ \\
\hline Highly susceptible (HS) & $>50$ & SMD-102, SMD-103 \\
\hline
\end{tabular}

Fig.1 Screening of saffron genotypes against Fusarium oxysporum on the basis of per cent disease incidence

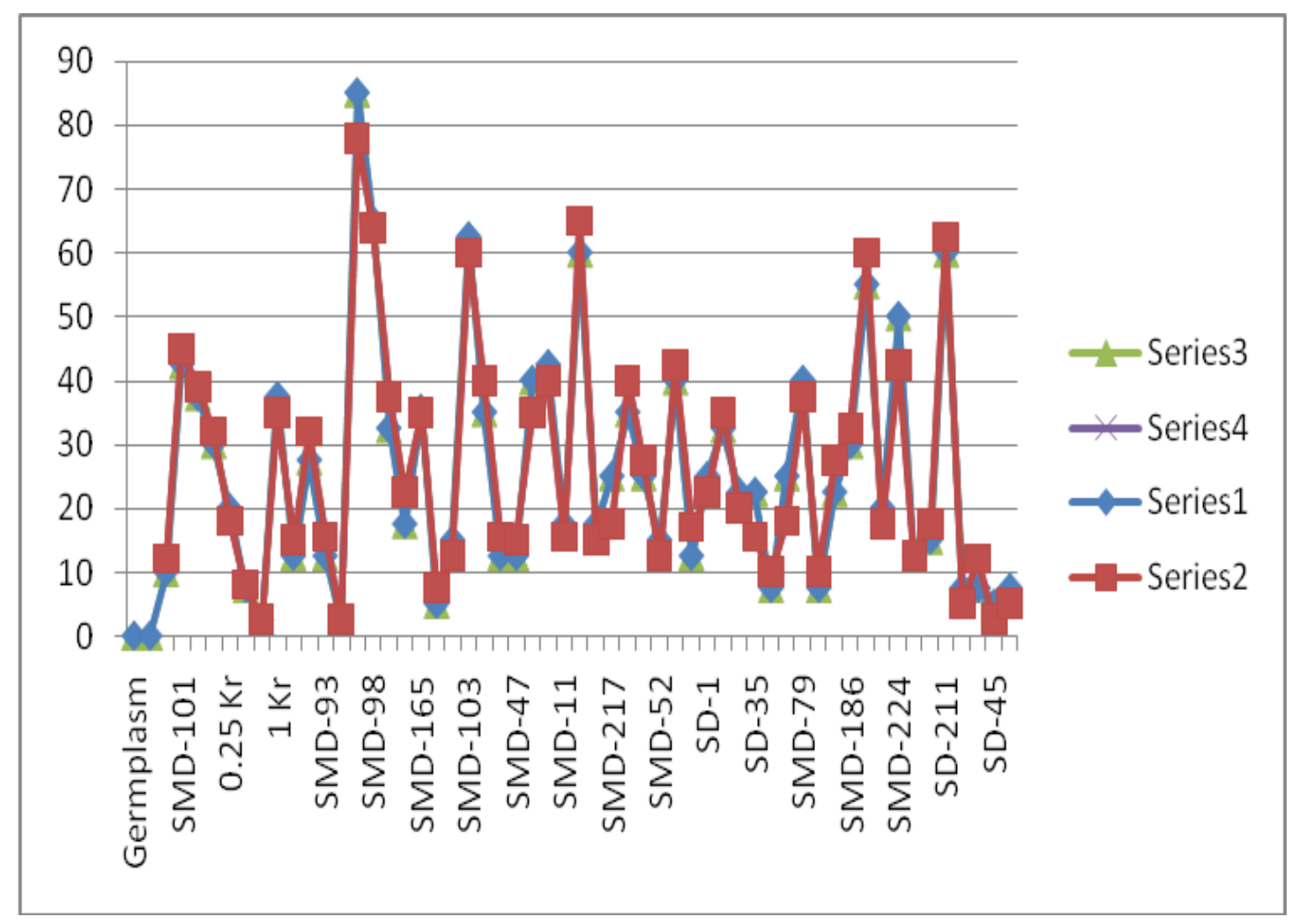


Fig.2 Screening of saffron genotypes against Fusarium oxysporum on the basis of per cent disease intensity

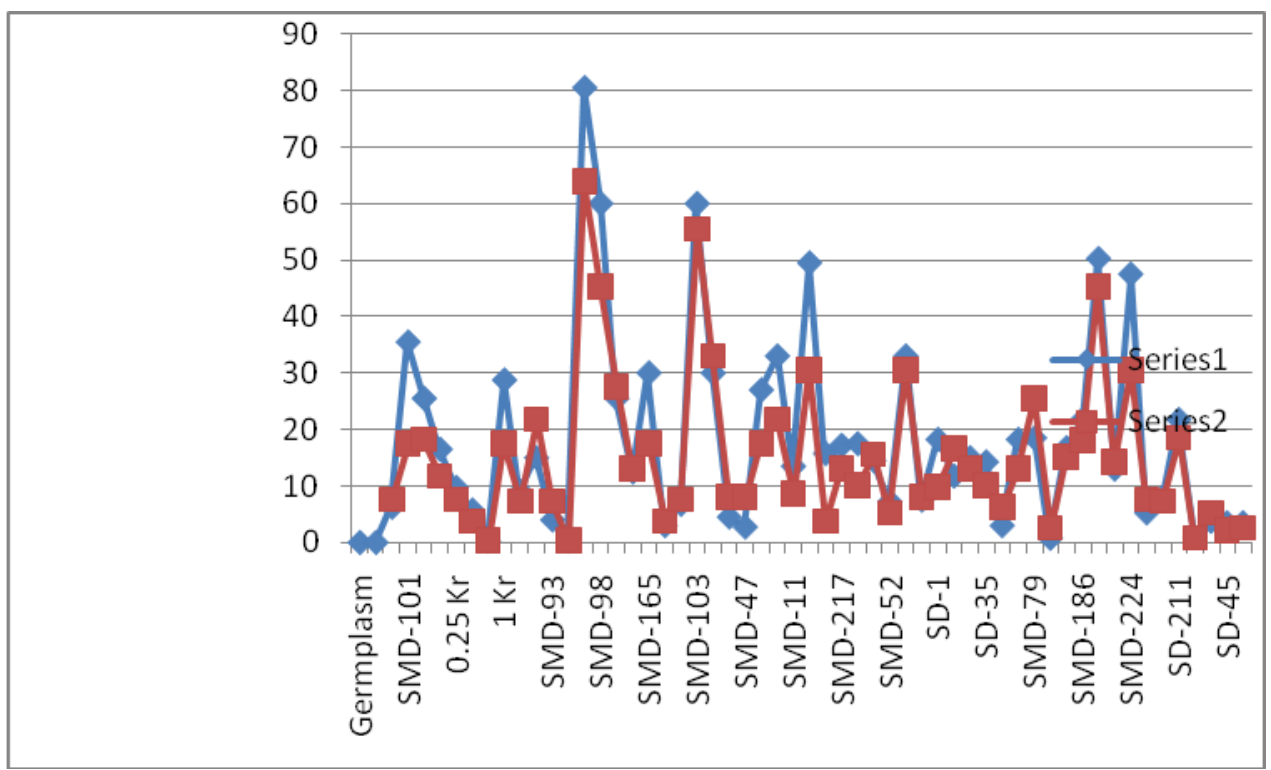

On an overall mean basis of two year data indicated that disease incidence and disease intensity ranged from 2.50 to 81.50 per cent and 0.25 to $72.25 \%$, respectively (Table 1 ; Figs. 1 and 2). The highest mean disease incidence $(81.50 \%)$ was recorded in genotype SDM-102 while lowest mean disease incidence $(2.5 \%)$ was recorded in $0.75 \mathrm{Kr}$ genotype. Among the screened germplasm, 'Highly Resistant' genotypes are $0.5 \mathrm{Kr}$, 0.75Kr, SMD-1, SMD-3 SMD-27, SMD-146, SD-147, SD-224 SD-45, SD-52, SD-68, while 'highly susceptible' genotypes were SMD102 and SMD-103. In the present investigation, the selection for resistance was based on the reaction of varieties on corms. It is necessary to test the reaction of the varieties at all stage because saffron crop become progressively more susceptible to Fusarium oxysporum with increasing age (Thakur, 1997) (Table 2). The difference in behaviour of varieties at different locations may be attributed to prevalence of different weather conditions and existence of different strains of Fusarium oxysporum (Singh and Saini, 1980). In the present investigation, the eleven genotypes which showed highly resistant reaction to saffron corm rot pathogen under natural epiphytotic conditions of Kashmir valley could be used as direct introduction or sources of resistance in hybridization programme.

\section{References}

Ahmed, M and Sagar, V 2007.Annual progress report on 'integrated management of corm/tuber rot of saffron and kalazeera (Horticuture Technology Mission-1 project 2.2) p 12.

Ahmed, M and Sagar, V. 2006. Annual progress report on 'integrated management of corm/tuber rot of saffron and kalazeera (Horticuture Technology Mission-1 project 2.2) p 10.

Dhar,A.K.1992. Bio-ecology and control of corm rot of saffron (Crocus sativa $\mathrm{L}$ ) Master's thesis Division of Plant Pathology, SKUAST-K (J \&K) p109

Gupta, S.K., Mathew, K.A., Shyam, K.R. and Sharma, A.K. 2000.Evaluation of French bean germplasm against angular leaf spot. Indian Phytopathology, 53: 488-489. 
Kalha, C.S, gupta, V and Gupta, D 2007.First report of sclerotial rot of saffron caused by Sclerotium rolfsii

Madan.C.L., Kapoor. B.M and Gupta, U.S.1967. Saffron. Economic Botany, 20: 377-385

Mir, G.M. 1992.Saffron agronomy in Kashmir, Gulshan Publishers, Srinagar, P163

Singh, A.K. and Saini, S.S. 1980. Inheritance of resistance to angular leaf spot (Isariopsis griseola Sacc.) in French bean (Phaseolus vulgaris L.). Euphytica, 29: 175-176.

Sud, A.K., Paul, Y.S and Thakur, B.R. 1999. Corm rot of saffron and its management. Journal of Mycology and Plant Pathology, 29:380-282.

Thakur R N, Singh C and Koul B L1992. First report of corm rot in Crocus sativus $\mathrm{L}$. Indian Phytopathology, 45: 278.

Wani, A 2004. Studies on corm rot of saffron (Crocus sativus L), Division of Plant Pathology, SKUAST-K, Srinagar (J\&K), India, P108+XVII.

Zargar, G. H 2002. Genetic variation of saffron and importance of quality seed corm In: Proceeding seminar/workshop on the development of saffron, SKUAST-K, pp: 25-36.

\section{How to cite this article:}

Sabiya Bashir, Mohammad Najeeb Mughal, F.A. Nehvi, S.A. Dar, Seerat un nissa, Z.A. Dar, S.A. Hakeem, R.A. Wani, Jahangeer A. Baba and Mehfooza Habib. 2017. Identification of Sources of Resistance in Saffron (Crocus sativus L.) to Fusarium oxysporum Causing Corm Rot Disease. Int.J.Curr.Microbiol.App.Sci. 6(11): 3660-3665.

doi: https://doi.org/10.20546/ijcmas.2017.611.428 